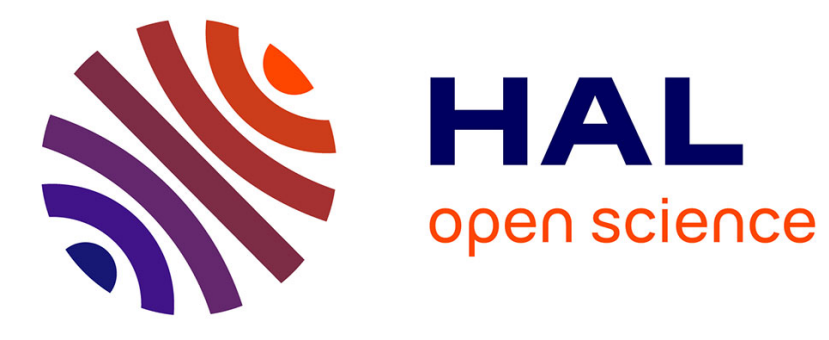

\title{
Study of a Heat Pump for Simultaneous Cooling and Desalination
}

\author{
Paul Byrne, Yacine Ait Oumeziane Ait Oumeziane, Laurent Serres, Thierry
}

Maré

\section{- To cite this version:}

Paul Byrne, Yacine Ait Oumeziane Ait Oumeziane, Laurent Serres, Thierry Maré. Study of a Heat Pump for Simultaneous Cooling and Desalination. Applied Mechanics and Materials, 2016, Advances in Heat Transfer, Flow Engineering and Energy Installations 819, pp.152-159. 10.4028/www.scientific.net/AMM.819.152 . hal-01253254

\section{HAL Id: hal-01253254 \\ https://hal.science/hal-01253254}

Submitted on 9 Jan 2016

HAL is a multi-disciplinary open access archive for the deposit and dissemination of scientific research documents, whether they are published or not. The documents may come from teaching and research institutions in France or abroad, or from public or private research centers.
L'archive ouverte pluridisciplinaire HAL, est destinée au dépôt et à la diffusion de documents scientifiques de niveau recherche, publiés ou non, émanant des établissements d'enseignement et de recherche français ou étrangers, des laboratoires publics ou privés. 


\title{
Study of a heat pump for simultaneous cooling and desalination \\ BYRNE Paul ${ }^{1, a^{*}}$, AIT OUMEZIANE Yacine ${ }^{1, b}$, SERRES Laurent ${ }^{1, \mathrm{c}}$ and MARE Thierry,d \\ ${ }^{1}$ Université Européenne de Bretagne \\ Laboratoire Génie Civil Génie Mécanique \\ IUT Génie Civil - 3 rue du Clos Courtel - BP 90422 \\ 35704 RENNES CEDEX 7 \\ apaul.byrne@univ-rennes1.fr, byacine.ait-oumeziane@univ-rennes1.fr, laurent.serres@univ-rennes1.fr, dhierry.mare@univ-rennes1.fr
}

Keywords: heat pump, cooling, desalination, membrane distillation, simultaneous production.

\begin{abstract}
Access to freshwater and energy resource management are two of the major concerns of the next decades. The global warming indicator, the decrease of rainfalls and the growing energy demand for cooling are correlated in the most populated agglomerations of the world. For industrial and social purposes, it seems vital to develop energy efficient systems for cooling and desalination. A heat pump can produce energy for space cooling and heat for desalination. Among the different desalination systems available, membrane distillation seems the most suitable solution to the condensing temperature level of a standard heat pump.

This article presents the development of a model of heat pump for simultaneous cooling and desalination by air-gap membrane distillation. The model was first developed using EES software and validated with experimental results from our laboratory and from the literature. The desalination unit was then optimised by numerical means in terms of dimensions and operating conditions using a bi-dimensional model with Matlab. A coupled system with a heat pump was finally simulated. The objective is to estimate the freshwater production depending on the cooling loads of a refrigerator placed in a building submitted to the conditions given by a weather data file in the Trnsys environment. The energy consumptions are compared to those of a standard reverse osmosis plant producing the same amount of freshwater associated to a chiller of same cooling capacity as the heat pump. The results show that the heat pump for simultaneous cooling and desalination offers interesting perspectives.
\end{abstract}

\section{Introduction}

The continuous growth of the world's population increases the global freshwater withdrawal in direct consumption by the people but also by agriculture and manufacturing sectors. The major part of the population lives on coastal areas where the most populated cities are situated and continue to attract more people. Besides, the cooling needs for air conditioning and refrigeration also grow due to new comfort requirements in emerging countries.

The correlation between high cooling demands, solar resource and possible desalination needs can be assessed (table 1). The method uses the population of agglomerations and their population growth rate [1]. The data on climate change (temperature increase) and the change in annual precipitation is available in the last document of the Intergovernmental Panel on Climate Change IPCC [2]. The cooling degree days (CDD) and solar resource were calculated using Trnsys software [3]. The cooling degree days are estimated to be the sum (on a yearly basis) of temperature difference between the average outdoor temperature (on a daily basis) and the indoor temperature that a cooling machine should compensate to satisfy the comfort requirements summed over a year. The indoor temperature is estimated at $18{ }^{\circ} \mathrm{C}$, a low value to roughly take into account internal gains and solar gains [4]. Table 1 shows that climate change has different impacts on the change in 
annual precipitations. Fewer precipitations are recorded in Senegal, Saudi Arabia and more are recorded in India and France. The solar resource and the cooling degree days are more or less correlated, except in Mumbai having a hot and humid climate. Fig. 1 presents the variation with respect to an average value of temperature difference due to climate change, cooling degree days, solar resource and possible desalination needs. The last index (possible desalination needs) is calculated as the yearly variation of the ratio of precipitation over population using the present population growth rate and the mean past change in precipitation over 50 years. If this index is positive, the ratio of precipitation per inhabitant is lower than the previous year. For each city, the population growth is such that the water precipitation per inhabitant is lower every year. The water precipitation decrease per inhabitant is here presented as a possible need for desalination. In these cities, this figure shows that if the solar resource and cooling needs are high, the possible desalination needs are high as well. To enunciate more general rules about this relationship, the study should be enlarged to other cities having other climates and other population growth rates.

Table 1: Comparison of populations, growth rate, climate change, cooling degree days and solar resource of five cities

\begin{tabular}{|c|c|c|c|c|c|c|c|}
\hline City & Country & $\begin{array}{l}\text { Population of } \\
\text { agglomeration } \\
\text { (millions of } \\
\text { inhabitants) }\end{array}$ & $\begin{array}{c}\text { Average growth } \\
\text { rate }\end{array}$ & $\begin{array}{c}\text { Climate change } \\
\text { from } 1901 \text { to } 2012 \\
\text { (temperature } \\
\text { variation range } \\
\text { in K) }\end{array}$ & $\begin{array}{l}\text { Change in annual } \\
\text { precipitation } \\
\text { range from } 1951 \\
\text { to } 2010 \text { (mm/year } \\
\text { per decade) }\end{array}$ & $\begin{array}{c}\text { Cooling Degree } \\
\text { Days }\end{array}$ & $\begin{array}{c}\text { Solar resource } \\
\left(\mathrm{kWh} / \mathrm{m}^{2} \text { per }\right. \\
\text { year) }\end{array}$ \\
\hline Dakar & Senegal & 2.9 & $4.30 \%$ & $0.8: 1.0$ & $-10:-25$ & 2343 & 2139 \\
\hline Mumbai & India & 21.4 & $2 \%$ & $1.0: 1.25$ & $+10:+25$ & 3435 & 1839 \\
\hline Paris & France & 10.7 & $0.55 \%$ & $1.25: 1.5$ & $+2.5:+5$ & 167 & 1037 \\
\hline Riyadh & Saoudi Arabia & 6.15 & $2.25 \%$ & $0.8: 1.0$ & $-2.5:-5$ & 3061 & 2217 \\
\hline Sydney & Australia & 4.675 & $1.35 \%$ & $1.0: 1.25$ & $-10:-25$ & 646 & 1608 \\
\hline
\end{tabular}

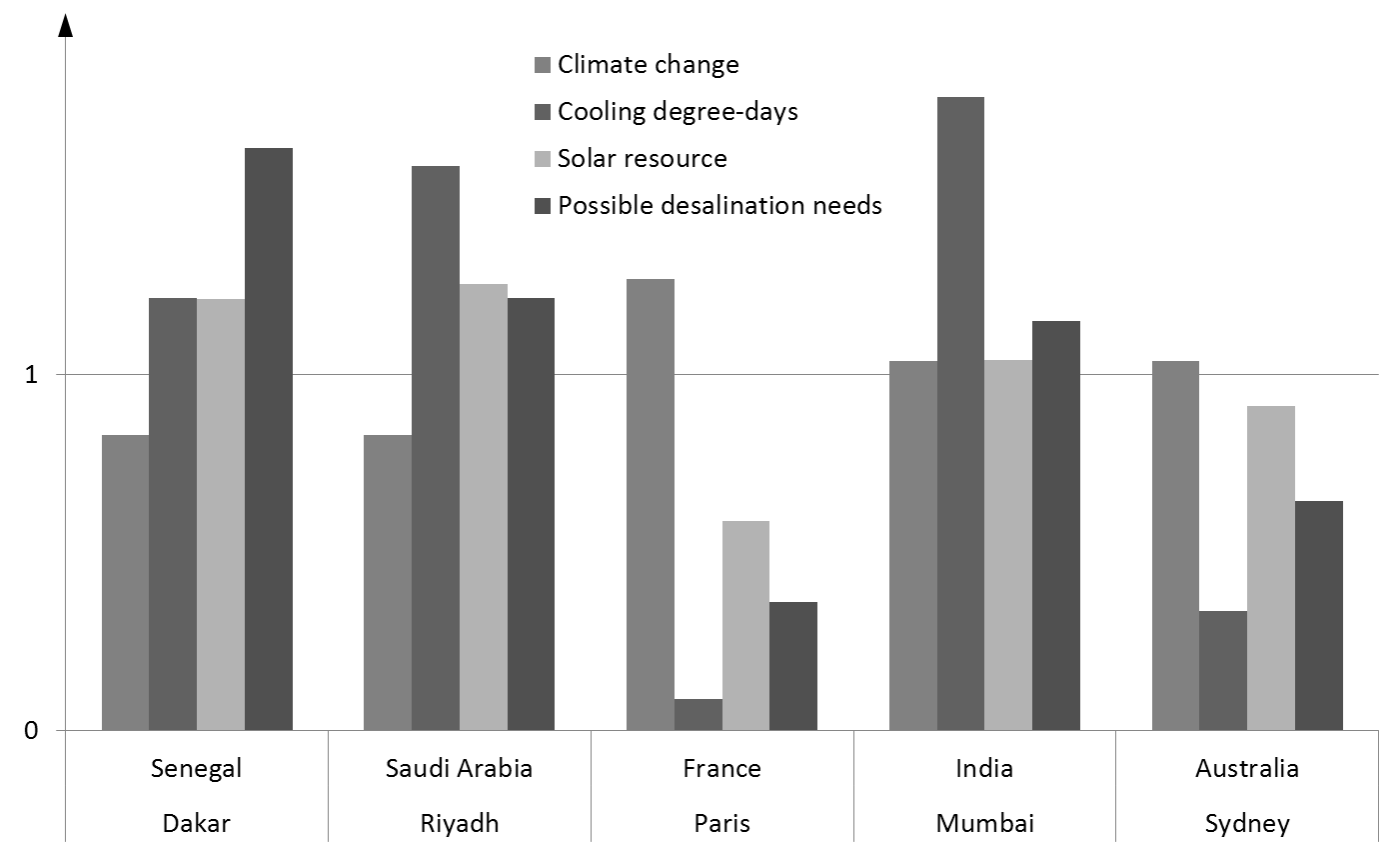

Figure 1: Relationship between relative values of climate change indicator, cooling degree days, solar resource and possible desalination needs of five cities

The critical global situation guides our research through the energy and water sectors. A path for energy savings is to operate a coupling of systems for simultaneous cooling and desalination. The laboratory background drives us towards heat pumping technology. Among the different desalination techniques available in the publication of Li et al. [5], membrane distillation works with temperature levels that are the most suitable with the condenser operation of a standard heat 
pump. Membrane distillation was first developed during the 1960s and then abandoned because of the difficulty to manufacture affordable and reliable membranes [6-7]. These membranes require the following list of specifications:

- negligible permeability to liquids

- high permeability to vapor

- high porosity

- hydrophobicity

- low thermal conductivity

- high resistance to chemical attacks and deposits

- sufficient mechanical resistance

Membrane technology has evolved and today a series of materials has these properties: polyvinylidene fluoride (PVDF), polytetrafluoroethylene (PTFE) or Teflon, polyacrylonitrile (PAN) [8] as well as polypropylene (PP) and polyethylene (PE) [6-7].

Recently, membrane distillation was judged economically viable if it were coupled to a renewable energy for thermal production [9]. The present study is part of a research project on energy recovering using heat pumps [10-17]. This article presents the last results of our simulations and very first experiments on the subject. The membrane distillation principle and the coupling to the heat pump are detailed. The model is then briefly presented and compared to the experimental results. Finally the results of a simulation study under the Trnsys environment involving the complete heat pump for simultaneous cooling and desalination are detailed and compared to those obtained by a chiller associated to a reverse osmosis unit.

\section{System principle}

The global installation scheme modeled using Trnsys software is presented in fig. 2 . The photovoltaic panels, the batteries and the $1 \mathrm{~m}^{3}$ refrigerator inside a $27 \mathrm{~m}^{3}$ building are modeled by Trnsys submodels, types 194, 47a and 56 respectively. A weather data file (Dakar in Senegal) provides air temperature and relative humidity and beam, diffuse and total radiations to the system. The rest of the components are modeled under EES environment (Engineering Equation Solver): the compressor, the condenser, which provides heat to the desalination unit, the expansion valve and the evaporator creating cold for the refrigerator. Trnsys Type66 is a bridge between Trnsys and EES. It recovers entries for EES models, calls EES and provides the results to the Trnsys model. The heat pump is seen in Trnsys as a Type 66 model. The electric motor of the compressor is assumed to be perfect.

The global system is controlled by the cooling needs. When the temperature increases above a certain limit inside the refrigerator, the on/off controller detects a cooling need and starts the compressor to carry out cooling until the temperature has reached the lower limit of the on/off control. The heat pump also produces heat at the condenser that is used in the membrane distillation unit. Freshwater production is in fact a by-product of cooling.

The membrane distillation (Air Gap Membrane Distillation) unit is modeled using EES software (Fig.3). The principle relies on a vapor transfer through a microporous and hydrophobic membrane due to a vapor pressure gradient created by a temperature gradient. Pure water vapor transfers through the membrane and condenses on a cold plate. The hot sea water is heated firstly by a recovering heat exchanger and secondly by a heat gain coming from the heat pump condenser. The cold fluid cooling the cold plate is the entering salted water. 


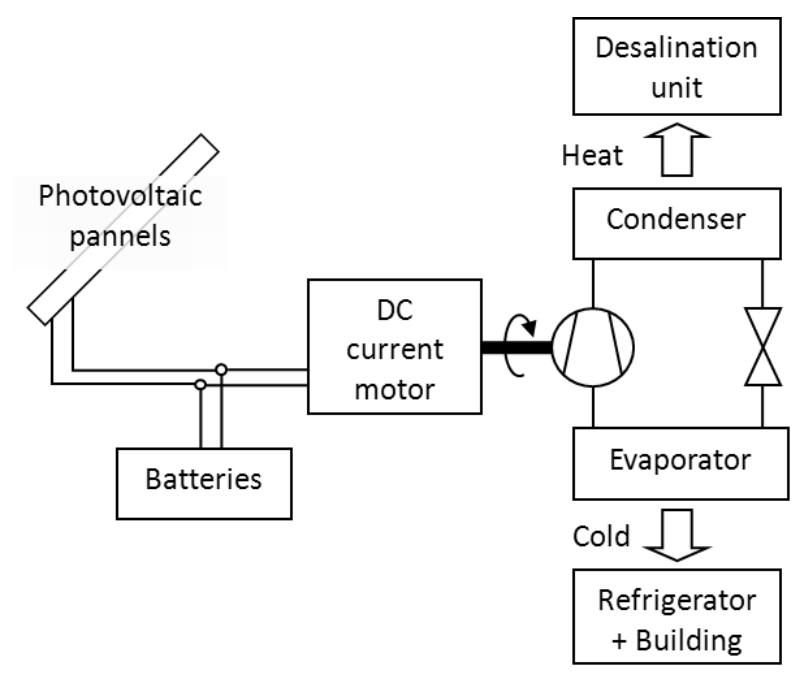

Figure 2: Scheme of the heat pump for simultaneous cooling and desalination

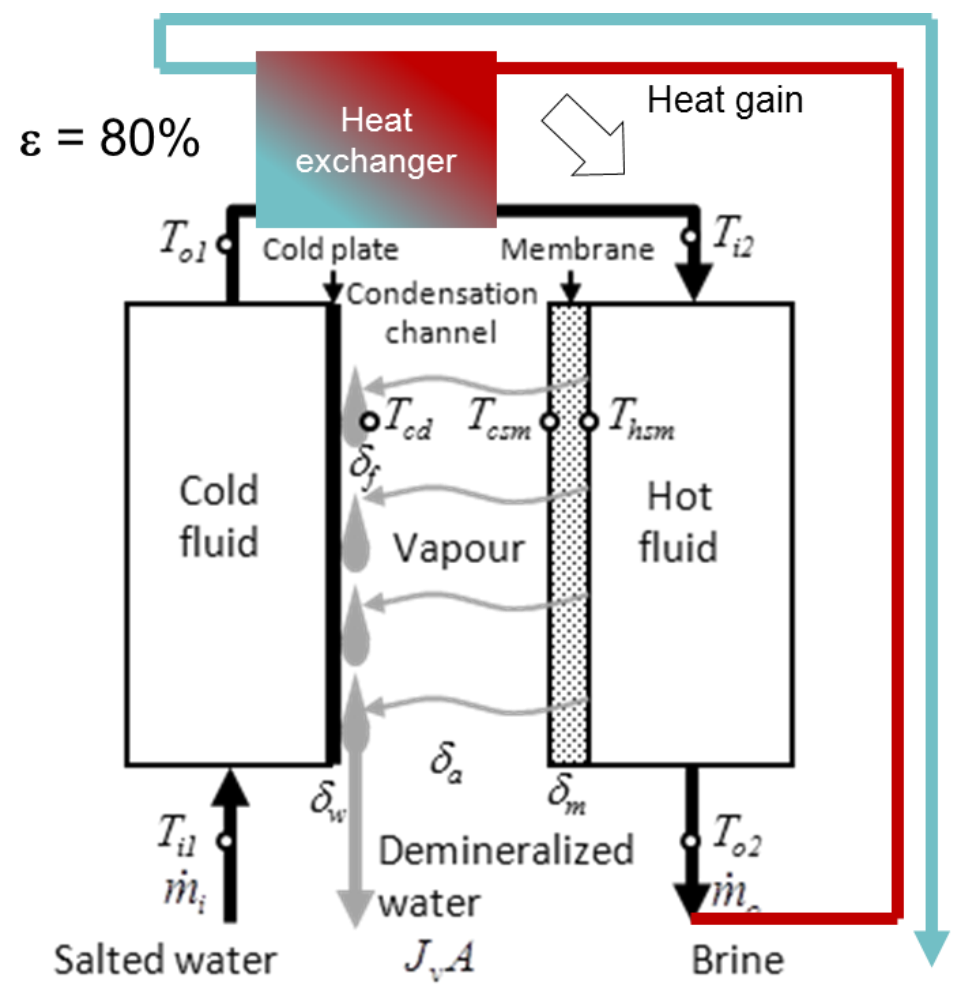

Figure 3: Scheme of the membrane distillation unit

\section{Model description and testing}

The heat and mass transfer models follows the ones proposed by previous publications [6-7;1011]. The vapor flux is given by Eq. 1 depending on the membrane permeability $K$ and the vapor pressure gradient $\Delta p_{v}$. The membrane permeability depends on the porosity $\varepsilon$, the vapor diffusion coefficient $D_{v / a}$, the molar mass of vapor $M_{v}$, the total pressure $p_{T}$, the tortuosity $\chi$, the membrane thickness $\delta_{m}$, the average air pressure $p_{a, a v e}$, the gas constant $R_{u}$ and the membrane average temperature $T_{m \text {,ave }}$ (Eq. 2).

$$
J_{v}=K \Delta p_{v}
$$




$$
K=\frac{\varepsilon D_{v / a} M_{v} p_{T}}{\chi \delta_{m} p_{a, a v e} R_{u}\left(T_{m, a v e}+273,15\right)}
$$

The heat transfer model considers parallel fluxes through the membrane; a convective heat transfer in the vapor and a conductive heat transfer inside the membrane matrix. Inside the air gap, the convective flux is assumed to occur only in the vapor and the conductive flux only in the air.

The parameters of the membrane were optimized in a previous publication [11]. Table 2 reports these values compared to the results of works published by Banat [18]. The air gap thickness was reduced to diminish the effect of the air gap in the total thermal resistance of the system to increase the part due to the membrane. It increased the temperature difference and the vapor pressure difference between the two surfaces of the membrane. Thus it increased the vapor transfer and the fresh water production. The flow rate was reduced to limit the heat loss in the brine even if there is a recovery heat exchanger. In total, the vapor flux was multiplied by 7 .

Table 2: Parameters of the membrane distillation unit

\begin{tabular}{|c|c|c|}
\hline Dimensions / Parameters & Model & Reference [18] \\
\hline Pore diameter $(\mu \mathrm{m})$ & 0.22 & N.C. \\
Porosity $(-)$ & 0.75 & N.C. \\
Tortuosity $(-)$ & 1.1 & N.C. \\
Air gap thickness $(\mathrm{mm})$ & 1.2 & 10 \\
Membrane thickness $(\mathrm{mm})$ & 0.12 & 0.11 \\
\hline Hot fluid temperature $\left({ }^{\circ} \mathrm{C}\right)$ & 40 & 40 \\
Flow rate $\left(\mathrm{m}^{3} / \mathrm{h}\right)$ & 3.2 & 5 \\
Vapor flux $\left(\mathrm{kg} \cdot \mathrm{h}^{-1} \cdot \mathrm{m}^{-2}\right)$ & 7.09 & 1.01 \\
\hline
\end{tabular}

Using these parameters, a comparison was carried out between results from the model and a simple experimentation (Fig. 4). The experimental set up consisted in a cell for permeability measurements (Millipore Amicon 8050). Salted water was heated in a kettle. It was then poured in the cell over a PVDF round Durapore GVWP09050 membrane. The metallic bottom of the permeability cell was set on a cold water bath. The amount of water passing through the membrane was weighed every 30 seconds using scales having a $0.01 \mathrm{~g}$ digital display. The tested membrane was hydrophilic and not hydrophobic as used in membrane distillation. The permeate solution was thus also salted. However, Fig. 5 still shows an unexpectable agreement between the results of the experiment and the ones given by the previously validated model. Therefore the model will be considered as correct for annual simulations.

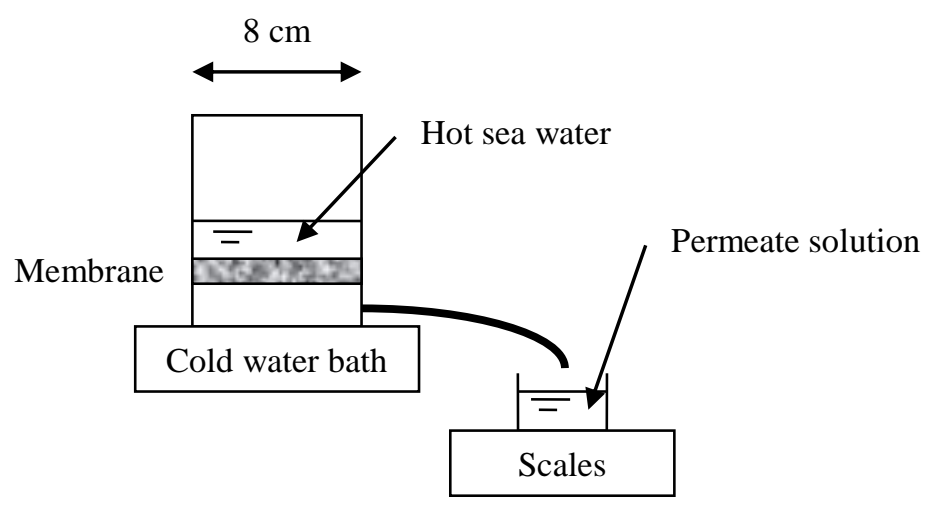

Figure 4: Experimental set up for the model comparison 


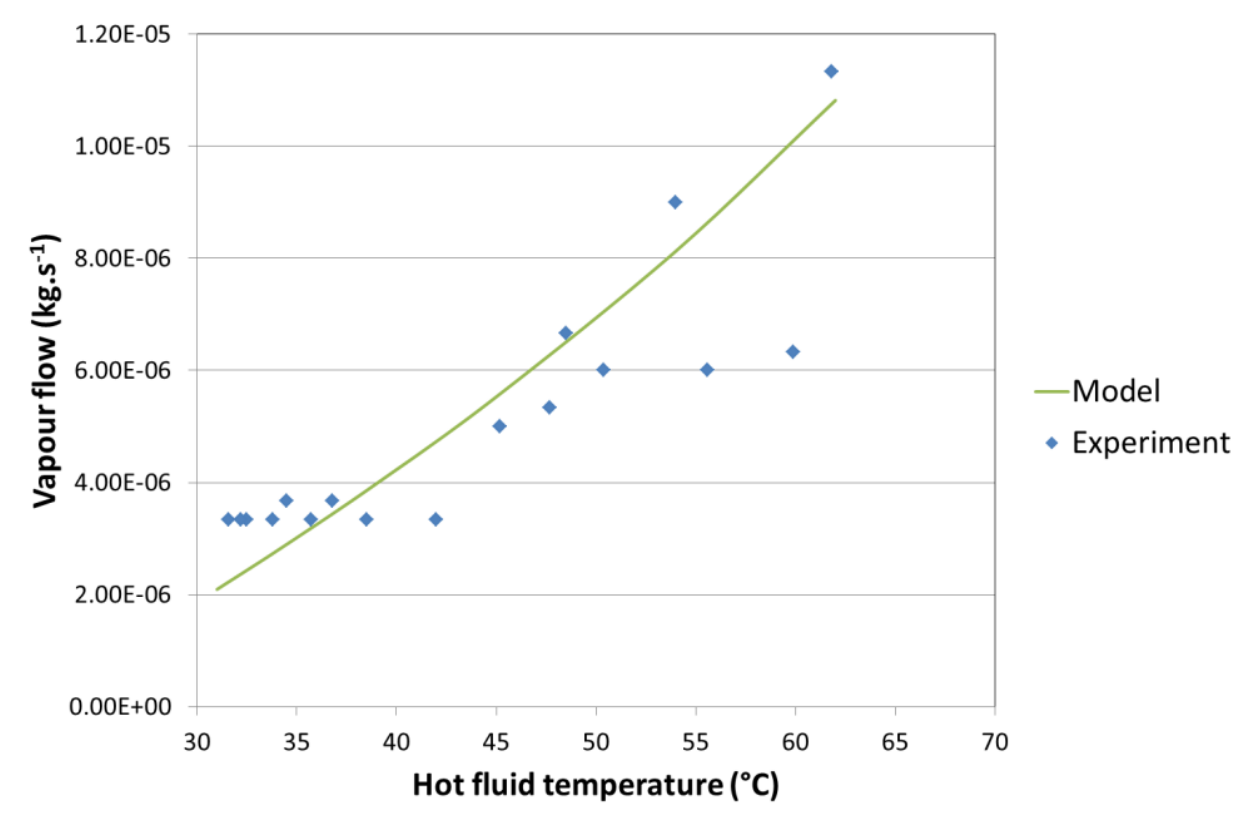

Figure 5: Model comparison with the results of a simple experiment

\section{Results from annual simulations and discussion}

The model dimensions were adapted to a whole scale membrane distillation unit coupled to a heat pump providing cooling for a refrigerator, which refrigerator is installed inside a building. Annual simulations were run using a co-solving technique implicating EES and Trnsys. Trnsys is the master software from which EES is called. The weather data file of Dakar (Senegal) is used.

The results of annual simulations are presented in Fig. 6. The cumulative electricity consumptions of two coupled systems are shown depending on the temperature of sea water at the entrance of the hot fluid canal in the membrane distillation unit. The first coupled system is the heat pump for simultaneous cooling and desalination. The annual electricity consumption is due to the cooling needs of the refrigerator. The condenser of the heat pump is connected to the desalination unit. The heat pump condensing temperature decreases following the hot fluid temperature. Thus the performance of the thermodynamic cycle increases, leading to lower electricity consumption by the compressor. The freshwater production decreases due to the lower temperature gradient inside the membrane desalination unit.

This heat pump is compared to a chiller with an outdoor air condenser associated to a reverse osmosis unit producing the same amount of freshwater than the membrane distillation unit coupled to the heat pump. The chiller electricity consumption is constant because the ambient conditions do not vary from case to case. The reverse osmosis unit is assumed to consume $3 \mathrm{kWh}$ of electricity per cubic meter of desalinated water. The decrease of freshwater production depending on the hot fluid inlet temperature leads to a nearly imperceptible decrease of electricity consumption of the chiller $+\mathrm{RO}$ association. The inlet temperature for which the consumptions of the two systems are equal is $33.3^{\circ} \mathrm{C}$. 


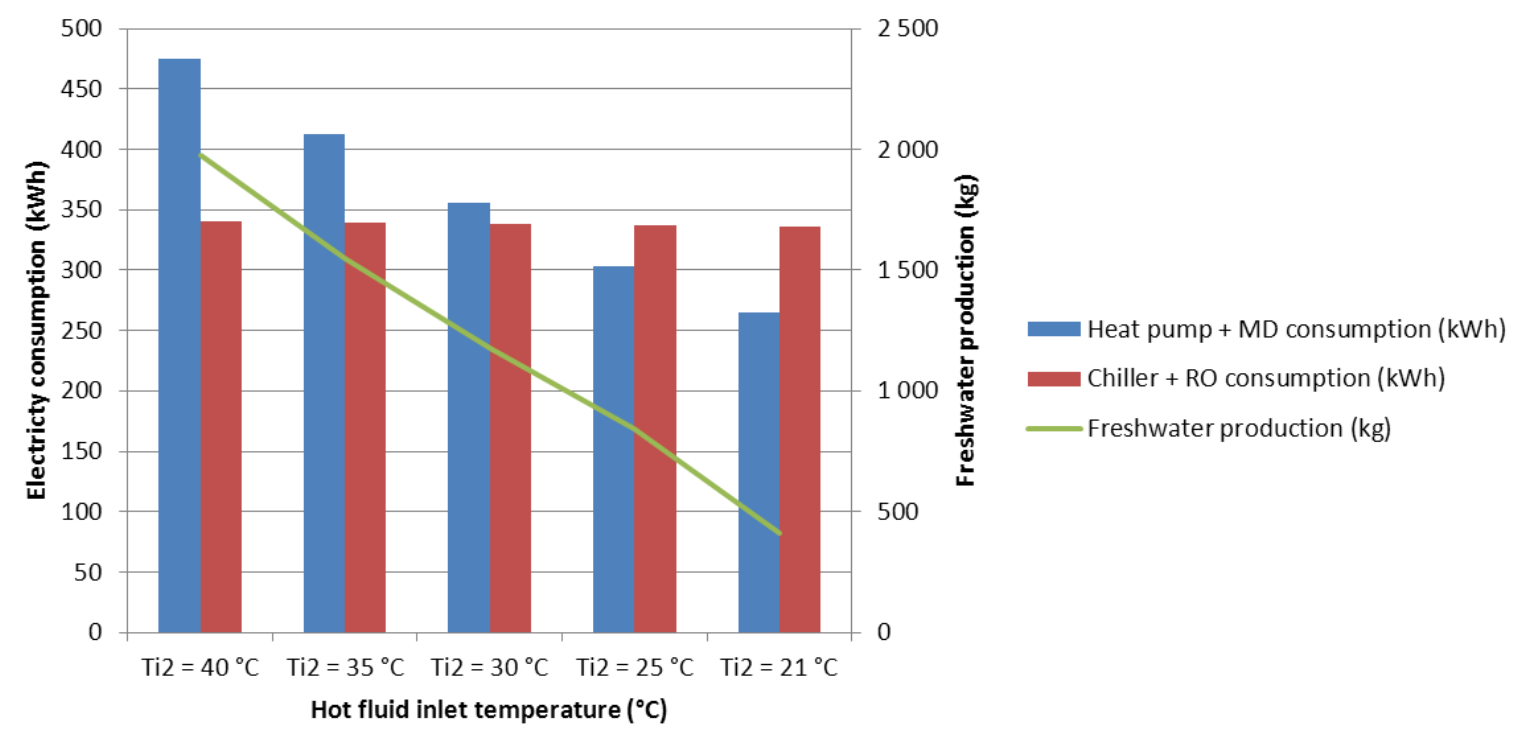

Figure 6: Results of annual simulations for Dakar (Senegal)

\section{Conclusion and perspectives}

This article presents a coupled system for simultaneous cooling and desalination. It is based on the analysis that the cooling and freshwater needs are increasing dramatically in regions of the world where resources are abundant in sun and seawater. The study focuses on the cooling and desalination heat pump system. The desalination method is membrane distillation, a technique that is now considered worthy of investigation thanks to recent progress made in membrane manufacturing. The system was modeled using EES and Trnsys software. The model is partially validated by a simple experimental study and by data from the literature. The simulation results confirm that the solution could be interesting with more work done on component optimization. The perspectives of this project are the construction of a prototype for real operation performance characterization and the improvement of the model for an expanded study of the heat pump behavior under other climates and for other cooling applications.

\section{References}

[1] http://www.citypopulation.de/

[2] T.F. Stocker, D. Qin, G.-K. Plattner, M. Tignor, S.K. Allen, J. Boschung, A. Nauels, Y. Xia, V. Bex, P.M. Midgley, IPCC, 2013: Summary for Policymakers. In: Climate Change 2013: The Physical Science Basis. Contribution of Working Group I to the Fifth Assessment Report of the Intergovernmental Panel on Climate Change, Cambridge University Press, Cambridge, United Kingdom and New York, NY, USA (2013).

[3] S.A. Klein, TRNSYS 17: A Transient System Simulation Program, Solar Energy Laboratory, University of Wisconsin, Madison, USA, http://sel.me.wisc.edu/trnsys (2010).

[4] M. Sivak, Potential energy demand for cooling in the 50 largest metropolitan areas of the world: Implications for developing countries. Energy Policy, 37 (2009) 1382-1384.

[5] C. Li, Y. Goswami, E. Stefanakos, Solar assisted sea water desalination: a review, Renewable and Sustainable Energy Reviews 19 (2013) 136-163.

[6] A.M. Alklaibi, N. Lior, Membrane-distillation desalination: status and potential, Desalination 171 (2004) 111-131.

[7] A.M. Alklaibi, N. Lior, Transport analysis of air-gap membrane distillation, Journal of Membrane Science 255 (2005) 239-253. 
[8] J.P. Mericq, Approche intégrée du dessalement d'eau de mer : Distillation membranaire sous vide pour la réduction des rejets salins et possibilités de couplage avec l'énergie solaire, Thèse de doctorat, INSA de Toulouse, France (2009).

[9] C. Charcosset, A review of membrane processes and renewable energies for desalination, Desalination 245 (2009) 214-231.

[10]P. Byrne, J. Miriel, L. Serres, R. Ghoubali, Etude simulée d'un système de dessalement d'eau de mer et de production de froid par thermofrigopompe couplée à des panneaux solaires, 2ème Colloque International Francophone en Energétique et Mécanique, CIFEM 2012, Ouagadougou, Burkina Faso (2012).

[11]P. Byrne, Y. Ait Oumeziane, L. Serres, J. Miriel, Etude simulée d'un système de distillation membranaire pour le dessalement d'eau de mer couplé à une thermofrigopompe, 3ème Colloque International Francophone en Energétique et Mécanique, CIFEM 2014, Moroni, Comores (2014).

[12]P. Byrne, J. Miriel, Y. Lenat, Design and simulation of a heat pump for simultaneous heating and cooling using HFC or CO2 as a working fluid, International Journal of Refrigeration 32 (2009) 1711-1723.

[13]P. Byrne, J. Miriel, Y. Lenat, Experimental study of an air-source heat pump for simultaneous heating and cooling - part 1: basic concepts and performance verification, Applied Energy 88 (2011) 1841-1847.

[14]P. Byrne, J. Miriel, Y. Lenat, Experimental study of an air-source heat pump for simultaneous heating and cooling - part 2: dynamic behaviour and two-phase thermosiphon defrosting technique, Applied Energy 88 (2011) 3072-3078.

[15]P. Byrne, J. Miriel, Y. Lenat, Modelling and simulation of a heat pump for simultaneous heating and cooling, Building Simulation: An International Journal 5 (2012) 219-232.

[16]P. Byrne, R. Ghoubali, J. Miriel, Scroll compressor modelling for heat pumps using hydrocarbons as refrigerants, International Journal of Refrigeration, International Journal of Refrigeration 41 (2014) 1-13.

[17]R. Ghoubali, P. Byrne, J. Miriel, F. Bazantay, Simulation study of heat pumps for simultaneous heating and cooling coupled to buildings, Energy and Buildings 72 (2014) 141-149.

[18]F.A. Banat, Membrane distillation for desalination and removal of volatile organic compounds from water, Doctoral Thesis, McGill University, Montreal, Canada (1994). 